\title{
Effect of multiple firings on shear bond strength of feldspathic porcelain to base metal alloys : An in-vitro study
}

\author{
Sangeeta J Nair ${ }^{1}$, Veena Hegde ${ }^{2}$, Tapan Teja Vallabhaneni ${ }^{3}$
}

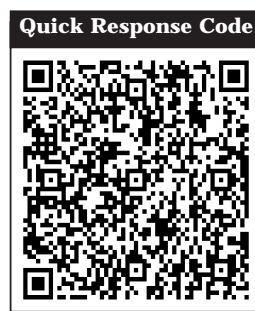

doi: 10.5866/2016.8.10089

${ }^{1}$ Assistant Professor

Department of Prosthodontics and Implantology,

Kamineni Institute of Dental Sciences,

Narketpally, Telangana, India-508254

2Professor

Department of Prosthodontics and I mplantology,

Manipal College of Dental Sciences,

Manipal, Karnataka, India-576 104

${ }^{3}$ University of Pittsburgh

School of Dental Medicine, 3501

Terrace Street, Pittsburgh 15213, Pennsylvania, USA,

\section{Article Info:}

Received: April 8, 2016

Review Completed: May 10, 2016

Accepted: J une 10, 2016

Available Online: September, 2016 (www.nacd.in)

(c) NAD, 2016 - All rights reserved

Email for correspondence:

sangeetajnair@gmail.com

\begin{abstract}
:
Background: The objective of the present study was to evaluate the effect of repeated firings on the metal-ceramic bond strength of cast $\mathrm{Ni}-\mathrm{Cr}$ and $\mathrm{Co}-\mathrm{Cr}$ alloy. Materials and Methods: Feldspathic porcelain (VITA VM 13 Zahnfabrik, Bad Sackinger, Germany) was fused to Ni-Cr alloy ( Wiron 99, Bego ) and Co-Cr alloy (Wirobond C, Bego ). Thirty cylindrical specimens were cast for each alloy. Feldspathic porcelain was applied on the upper surface of the cylinders and fired according to manufacturers' instructions. In each group, specimens were divided into 3 subgroups based on repeated firings $(3,5,7)$. Shear bond strengths were determined in a universal testing machine (INSTRON 3366, Norwood, USA), with a 2500-kgf load cell and crosshead speed of $1 \mathrm{~mm} / \mathrm{min}$ ), using a custom made steel apparatus. Failure loads were statistically analyzed first with the one-way ANOVA, and then compared with the Student t test. Results: One-way ANOVA test results showed no statistical differences between the metal-ceramic bond strength of $\mathrm{Ni}-\mathrm{Cr}$ alloy $(\mathrm{P}=0.127)$ and $\mathrm{Co}-\mathrm{Cr}$ alloy $(\mathrm{P}=0.087)$ after firing 3 , 5 , and 7 times. The mean shear bond load $(\mathrm{N})$ for $\mathrm{Ni}-\mathrm{Cr}$ alloy group $(860.58 \pm 40.81)$ was significantly higher $(p=0.001)$ than $\mathrm{Co}-\mathrm{Cr}$ alloy group (679.18 \pm 43.31 ). Conclusion: The mean shear bond strength for the metal ceramic systems tested were not significantly affected by multiple firings and were considered as clinically acceptable for metal-ceramic restorations.
\end{abstract}

Key words: base-metal alloys, multiple firings, metal-ceramic alloys, shear bond strength.

\section{INTRODUCTION}

Metal-ceramic restorations have been used in dentistry for over a century due to their excellent fracture resistance. ${ }^{1-3}$ Currently, base metal alloys have replaced the high noble and noble metal casting alloys by allowing fabrication of long span and cantilevered FPDs with lesser thickness and greater rigidity. ${ }^{4}$ Moreover, higher melting range reduces the risk of distortion and sagging of metal substructure during porcel ain firing. ${ }^{5}$ Dueto optimal mechanical properties, low density and cost considerations, base metal alloys are considered as a viable alternative to precious alloys in metalceramic restorations. ${ }^{6-8}$ H owever, restoration's longevity depends on the bond strength between the metal core and the veneering porcelain. Residual stress gradients, interfacial chemistry, and the interfacial morphology are the main factors that influence the success of a ceramic-metal bond. ${ }^{9}$ 
Multiple firing procedures are usually necessary for the fabrication of metal-ceramic restorations to match the esthetics of natural dentition, especially when using the standard layering technique. It has been found that repeated firings of the base metal alloys enhance the formation of excessive oxide layers which could lead to fracture through the metal oxide. ${ }^{10}$ F urthermore, repeated firings may also produce changes in micro-crack density and partial decoupling of the leucite from the surrounding glass matrix, resulting in a lowering of the bulk thermal expansion of the porcelain. ${ }^{11}$ Large differences in thermal expansion coefficients may form residual stress gradients across the metal- ceramic interface during processing, with a subsequent decrease in bond strength. ${ }^{12,13}$ Therefore, the purpose of the present study was to determinethe effect of repeated firings on the shear bond strength of feldspathic porcelain veneered to conventional cast base metal alloys.

\section{MATERIALS AND METHODS:}

Feldspathic porcelain (VMK 95, VITA Zahnfabrik, Bad Sackingen, Germany) was fused to two base metal alloys - Ni-Cr alloy (Wiron-99, Bego Ltd., Germany) and Co-Cr alloy (Wirobond-C, Bego Ltd., Germany) to form two porcelain - metal groups (Table 1).

\section{Preparation of cast specimens:}

A metal die was prepared according to the sample dimensions ( cylindrical rod, $8 \mathrm{~mm}$ in height; and $4 \mathrm{~mm}$ in diameter ) specified by de Melo et al ( Figure1) and its silicone index ( Polyvinyl siloxane, Aquasil soft putty, Dentsply ) was used to standardize the waxed parts for formation of the metallic aspect of the specimen. ${ }^{14}$ Sixty wax molds were made using inlay wax ( Bego, Germany) and invested in a phosphate bonded investment material ( Bellasun, Bego ). Casting was done using centrifugal casting machine (OKAY PLUS, Galoni, Italy), through the lost wax casting technique, to obtain thirty correspondent metallic portion of the specimens for each alloy ( $\mathrm{Ni}-\mathrm{Cr}$ alloy, Wiron-99, Bego; and Co-Cr alloy, Wirobond C, Bego). Metal surface treatment was performed by degassing and grit-blasting the specimens with aluminum oxide (100 $\mu$ ) under 2-bar pressure for 10 seconds (Model Microjet II, EDG, Sao Carlos, SP, Brazil). The specimens were cleaned with tap water, isopropyl alcohol and then allowed to dry for 10 minutes.

\section{Veneering procedure}

Two thin layers of opaque porcelain powder (VMK 95, VITA Zahnfabrik, Bad Sackingen, Germany) in a paste/liquid mix were applied on the metal specimens using a brush and fired according to the manufacturer's instructions (Porcelain furnace, Vacumat 40 ; Vita Zahnfabrik, Bad Sackingen, Germany). Dentin porcelain was condensed to a height of $4 \mathrm{~mm}$ in a slightly oversized silicone putty index to compensate for the contraction generated during the first firing cycle (Figure 2) and submitted to dentin firing to achieve the final dimensions of the samples as described in Figure 1. The specimens within each group were randomly divided into three subgroups and subjected to repeated firings as per manufacturers' instructions (Table 2).

\section{Testing Procedures}

The mechanical shear bond test was performed using a custom made steel apparatus consisting of two independent parts ( $A$ and $B$ ), that concentrated the tension at the metal-ceramic interface. The Part A was cylindrical with a flat interior adaptation that enabled insertion of the other Part B, comprising of an upper cylindrical prolongation to serveas a piston during the mechanical evaluation of the specimens (Figure 3). The specimens were inserted into the apparatus through an orifice ( $4 \mathrm{~mm}$ diameter) on the flat side of both the parts, that lodged the metallic portion of the specimen in Part $A$ and the ceramic portion in Part B (Figure 4). The shear bond test was conducted in a universal testing machine (INSTRON 3366, Norwood, USA), with a 2500-kgf load cell that applied shear forces at the metalporcelain interface at a crosshead speed of $1 \mathrm{~mm}$ / min until failure occurred. Failure loads were recorded in Newton ( $\mathrm{N}$ ) and results were converted into MPa using the following formula:

$$
\text { Stress (M pa) }=\frac{\text { Load }}{\pi r^{2}}=\frac{\text { Load }}{3.14 \times 4}=\frac{\text { Load }}{12.56\left(\mathrm{~mm}^{2}\right)}
$$

\section{Statistical Analysis}

One-way ANOVA test was used $(p \cdot 0.05)$ for statistical analysis of the data. The mean values of the two groups were compared using student's- $t$ test. A statistical software package (SPSS 15.0; SPSS, Inc., Cary, NC, USA) was used for the analysis. 


\section{RESULTS}

The mean bond strength values and standard deviations using the one-way ANOVA test are presented in Table 3 and 4. Results showed no statistically significant difference between shear bond strength values in the $\mathrm{Ni}-\mathrm{Cr} /$ porcelain and $\mathrm{Co}-$ $\mathrm{Cr}$ alloy/porcelain combinations $(\mathrm{p}=0.05)$ after 3,5 and 7 repeated firings. The Student t test results showed that Group A (68.52 MPa \pm 40.81 ) had significantly higher mean shear bond strength value than Group B (54.07 MPa \pm 43.31) (Table 5).

\section{DISCUSSION}

The suitable oxidation of metal and interdiffusion of ions between the metal and porcelain is believed to be the main adhesion mechanism in PFM restorations. Base metal alloys with nickel and chromium, form excessive oxide layers that may increase the risk of porcelain fracture. ${ }^{15}$ Mclean demonstrated that the coefficient of thermal expansion of vita porcelain was decreased due to nickel and chromium oxide and induced

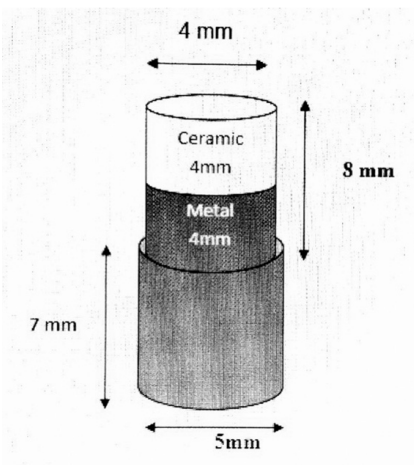

Figure 1: Schematic illustration of specimen dimensions

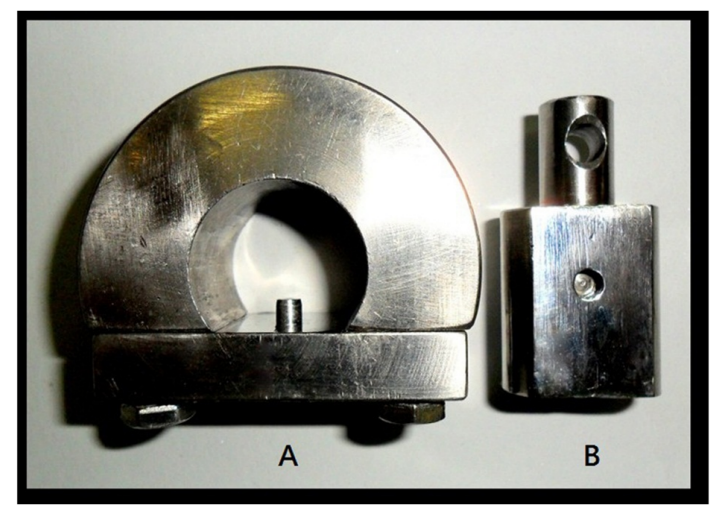

Figure 3: Custom made apparatus stresses, leading to failure of the non-precious metalceramic restorations. ${ }^{16}$ The thickness of oxide layer formed during the oxidation process depends on the alloy composition, preparation of metal and length of firing. It is common laboratory practice to remove some of the oxides before porcelain application by means of grit-blasting after de-gassing. ${ }^{17}$ Pask and Tomsia found that the amount of $\mathrm{Ni}_{2} \mathrm{O}$ and $\mathrm{Cr}_{2} \mathrm{O}_{3}$ was less at the metal-porcelain interface in the argon fired specimens than in the vacuum-fired ones. ${ }^{18}$ Barghi et al measured the fracture strength of repeatedly fired porcelain veneered to high noble and base metal alloy crowns and reported that multiple firings decreased the fracture strength in high noble alloys but did not significantly affect base metal alloys. ${ }^{10}$ The Selective laser melting (SLM) metal ceramic system showed improved porcelain adherence compared with conventional cast methods after 5 and 7 firings. ${ }^{19}$

In the present study, cast $\mathrm{Ni}-\mathrm{Cr}$ and $\mathrm{Co}-\mathrm{Cr}$ alloy were used to investigate the metal-ceramic bond

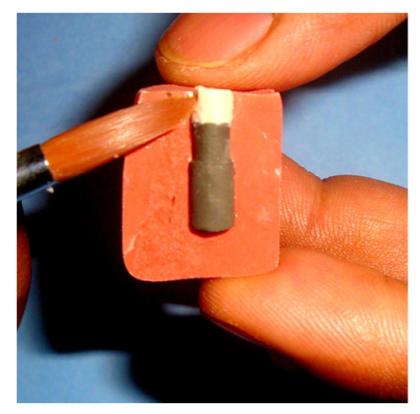

Figure 2 : Silicone putty index to standardize porcelain application

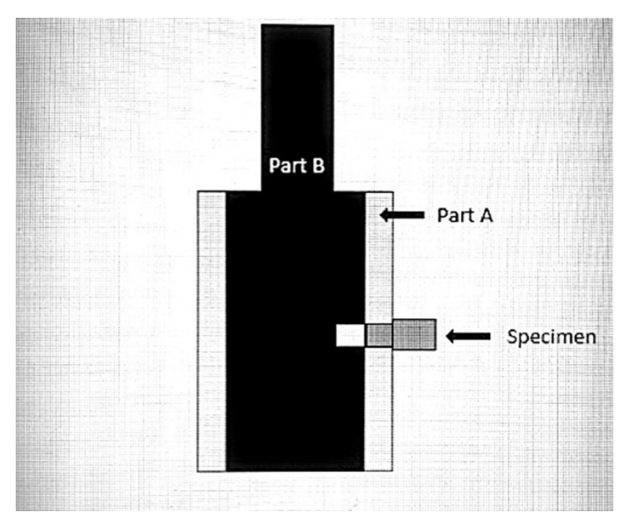

Figure 4: Schematic illustration of the position of specimen during testing 
Table 1: Experimental groups division

\begin{tabular}{llc} 
Group & Porcelain/Metal & $\begin{array}{c}\text { Number } \\
\text { of samples }\end{array}$ \\
Group A & Vita VMK 95/Ni-Cr & 30 \\
\hline Group B & Vita VMK 95/Co-Cr & 30 \\
\hline
\end{tabular}

Table2: Experimental group subdivisions

$\begin{array}{cccc}\begin{array}{c}\text { Group A } \\ \text { sub }\end{array} & \begin{array}{c}\text { Group B } \\ \text { sub- } \\ \text { divisions }\end{array} & \begin{array}{c}\text { Repeated } \\ \text { fivisions }\end{array} & \begin{array}{c}\text { Number } \\ \text { of samples }\end{array} \\ & \text { cycles } & \end{array}$

\begin{tabular}{llll} 
A0 & B0 & 3 & 10 \\
\hline A1 & B1 & 5 & 10 \\
\hline A2 & B2 & 7 & 10 \\
\hline
\end{tabular}

Table 3: One-way ANOVA for mean shear bond loads between the Sub-groups of Group A

\begin{tabular}{cccc} 
Group A (Ni-Cr) & Mean & SD & P-value \\
A0 & 875.33 & 43.79 & 0.127 \\
\hline A1 & 866.59 & 40.28 & \\
\hline A2 & 839.81 & 32.62 & \\
\hline
\end{tabular}

SD: Standard deviation

Table 4: One-way ANOVA for mean shear bond
loads between the Sub-groups of Group B
\begin{tabular}{|cccc} 
Group B (Co-Cr) & Mean & SD & P-value \\
\hline B0 & 702.17 & 34.83 & 0.087 \\
\hline B1 & 674.94 & 42.94 & \\
\hline B2 & 660.42 & 44.60 & \\
\hline
\end{tabular}

SD: Standard deviation

Table 5: Comparison of Mean shear bond loads between Group A \& Group B using student-t test

\begin{tabular}{cccc} 
Group & Mean & SD & p-value \\
A (Ni-Cr) & 860.58 & 40.81 & $\varangle 0.001$ \\
\hline B (Co-Cr) & 679.18 & 43.31 & \\
\hline
\end{tabular}

SD: Standard deviation strength after multiple firings. Various tests designed by researchers to evaluate bond strengths of different metalloceramic systems can be classified according to the nature of stresses created such as shear, tensile, flexural strength, torsion or a combination of the previous. ${ }^{20}$ Although, no single test method can be universally considered to be the most valid for clinical implications, shear tests are widely used because of its relative simplicity of use, ease of specimen preparation and rapid production of test results. ${ }^{21,} 22$ The base metal alloys mostly indicate a predominance of interface failures, suggesting a weak oxide layer at the metal-ceramic interface. ${ }^{23}$ Therefore, in the present study shear bond strength was tested through a custom made apparatus to direct the tension mostly to the metalceramic interface. Although, different values of bond strength are expected with different testing modes, the minimum of $51 \mathrm{MPa}$ has been suggested as lower limit for bond strength. ${ }^{24}$ Multiple firings (3, 5 and 7) had no significant effect on shear bond strength of both the test groups. The mean shear bond strength of $\mathrm{Ni}-\mathrm{Cr}$ alloy group (68.52 $\mathrm{MPa}$ ) was higher than the $\mathrm{Co}-\mathrm{Cr}$ alloy group (54.07 MPa). However, an advantage of $\mathrm{Co}-\mathrm{Cr}$ alloys over $\mathrm{Ni}-\mathrm{Cr}$ alloys is its great biocompatibility relative to the allergenic potential associated with beryllium and nickel. ${ }^{25}$ Therefore, cobalt-chromium alloys can be used as a suitable base-metal alternative for patients allergic to nickel. Further evaluation of the effects of other parameters such as different firing temperatures and thermocycling immersion times, on alternative alloys used in metal-ceramic restorations is required before making any clinical recommendations.

\section{CONCLUSION}

Within the limitations of this study, selected cast base metal alloys and veneering porcelain combinations were found to be suitable for clinical use as repeated firings did not significantly affect the metal-ceramic bond strength.

\section{REFERENCES}

1. Wataha J C. Alloys for prosthodontic restorations.J Prosthet Dent 2002; 87:351-63.

2. J arad FD, Russell MD, Moss BW. The use of digital imaging for colour matching and communication in restorative dentistry. Br Dent J 2005; 199:43-9.

3. Wee AG, Chen WY, J ohnston WM. Color formulation and reproduction of opaque dental ceramic. Dent Mater 2005; 21:665-70. 
4. Wu Y, Moser J B, J ameson LM, Malone WF. The effect of oxidation heat treatment on porcelain bond strength in selected base metal alloys. J Prosthet Dent 1991; 66(4):43944.

5. Watanabe I, Benson AP, N guyen K. Effect of heat treatment on joint properties of laser-wel ded Ag-Au-Cu-Pd and $\mathrm{Co}-\mathrm{Cr}$ alloys. J Prosthodont 2005; 14:170-4.

6. Moffa J P. Alternative dental casting alloys. Dent Clin North Am 1983; 27:733-46.

7. Brown D, Curtis RV. Alternatives to gold. Dent U pdate 1992; 19:325-6, 328-30.

8. Wataha J C, Messer RL. Casting alloys. Dent Clin North Am 2004; 48:499-512.

9. Wagner WC, Asgar K, Bigel ow WC, Flinn RA. Effect of interfacial variables on metal porcelain bonding. J Biomed Mater Res 1993; 27:531-7.

10. Barghi N, McKeehan-Whitmer M, Aranda R. Comparison of fracture strength of porcelain-veneered-to-high nobleand base metal alloys. J Prosthet Dent 1987; 57:23-6.

11. Mackert, J .R., J r.; Williams, A.L. Microcracks in dental porcelains and their behavior during multiplefiring. J Dent Res 1996, 75:1484-90.

12. Stannard J G, Kanchanatawewat K. Effect of multiple firing on the bond strength of selected matched porcelain-fusedto-metal combinations. J Prosthet Dent 1990; 63:627-9.

13. SC Lopes, V. O Pagnano, J .M.D Rollo, M.B. Leal \& O.L Bezzon: Correlation between metal-ceramic bond strength $\&$ coefficient of linear thermal expansion difference. J Appl Oral Sci 2009; 17(2):122-8.

14. De Melo RM, Travassos AC, Neisser MP. Shear bond strengths of a ceramic system to alternative metal alloys. J Prosthet Dent 2005; 93(1):64-9.
15. Baran GR. Oxide compounds on Ni-Cr alloys. J Dent Res 1984; 63:1332-4

16. Mclean J W. The search for improved metal-ceramics. Quint Dent Tech 1978; 2:51-9.

17. Hofstede TM, Ercoli C, Gracer GC, Tallents RH, Moss ME, Zero DT. Influence of metal surface finishing on porcelain porosity and beam failure loads at the metal-ceramic interface. J Prosthet Dent 2000; 84:309-17.

18. Pask 」 A, Tomsia AP. Oxidation and ceramic coatings on 80 $\mathrm{Ni} 20 \mathrm{Cr}$ alloys. J Dent Res 1988; 9:1164-71.

19. Ren XW, Zeng L, Wei ZM, Xin XZ, Wei B. Effects of multiple firings on metal-ceramic bond strength of $\mathrm{Co}-\mathrm{Cr}$ alloy fabricated by selective laser melting. The J Prosthet Dent 2016; 115(1):109-14.

20. Hammad IA, Talic YF. Designs of bond strength tests for metal ceramic complexes: Review of the literature. J Prosthet Dent 1996; 75:602-8.

21. Hadavi F, Hey J H, Ambrose ER, Louie PW, Shinkewski DJ The effect of dentin primer on the shear bond strength between composite resin and enamel. Oper Dent 1993; 18:61-5.

22. Atluri KR, Vallabhaneni TT, Tadi DP, Vadapalli SB, Tripuraneni SC, Averneni P. Comparative Evaluation of Metal-ceramic Bond Strengths of Nickel Chromium and Cobalt Chromium Alloys on Repeated Castings: An In vitro Study. J Int Oral Health 2014; 6(5):99-103.

23. Choi BK, Han J S, Yang J H, Lee J B, Kim SH. Shear bond strength of veneering porcelain to zirconia and metal cores. Jdv Prosthodont 2009; 1:129-35.

24. Anusavice, KJ . Phillips' science of dental materials, 11th ed., W.B. Saunders, Philadel phia, 2006, pp. 621-654.

25. Roberts HW, Berzins DW, Moore BK, Charlton DG. MetalCeramic Alloys in Dentistry: A Review. Int J Prosthodont, 2009; 18:188-94.

\section{Gain quick access to our journal online View our journal at www.nacd.in}

